\title{
Origin and Fate of Vanadium in the Hazeltine Creek Catchment following the 2014 Mount Polley Mine Tailings Spill in British Columbia, Canada
}

\author{
Karen A. Hudson-Edwards, ${ }^{*}{ }^{\dagger} \odot$ Patrick Byrne, ${ }^{\ddagger \odot}$ Graham Bird, ${ }^{\S}$ Paul A. Brewer, ${ }^{\|}$Ian T. Burke, ${ }^{\perp \odot}$
} Heather E. Jamieson, ${ }^{\#}$ Mark G. Macklin, ${ }^{@}$ and Richard D. Williams ${ }^{\nabla}$

${ }^{\dagger}$ Environment \& Sustainability Institute and Camborne School of Mines, University of Exeter, Penryn, Cornwall TR10 9FE, U.K.

${ }^{\ddagger}$ School of Natural Sciences and Psychology, Liverpool John Moores University, Liverpool L3 3AF, U.K.

${ }^{\S}$ School of Natural Sciences, Bangor University, Bangor, Gwynedd LL57 2UW, U.K.

"Department of Geography and Earth Sciences, Aberystwyth University, Penglais, Aberystwyth, Ceredigion SY23 3DB, U.K.

${ }^{\perp}$ School of Earth and Environment, University of Leeds, Leeds LS2 9JT, U.K.

\#Department of Geological Sciences and Geological Engineering, Queen’s University, Kingston, Ontario K7L 3N6, Canada

${ }^{\circledR}$ Lincoln Centre for Water and Planetary Health, School of Geography, College of Science, University of Lincoln, Brayford Pool, Lincoln, Lincolnshire LN6 7TS, U.K.

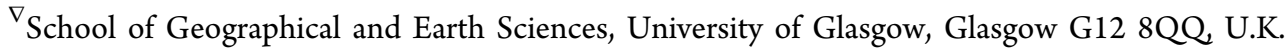

Supporting Information

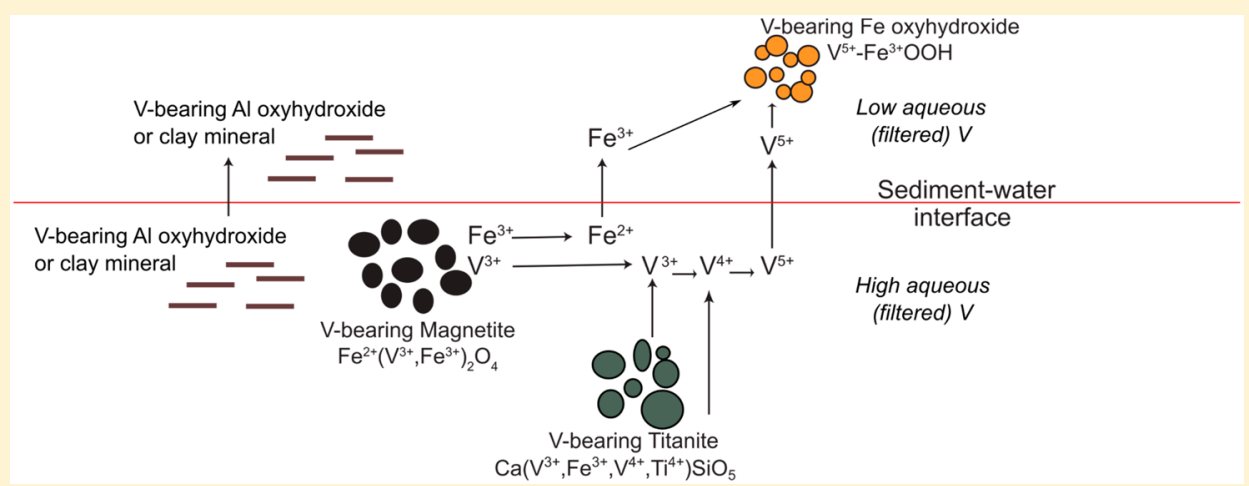

ABSTRACT: Results from the analysis of aqueous and solid-phase V speciation within samples collected from the Hazeltine Creek catchment affected by the August 2014 Mount Polley mine tailings dam failure in British Columbia, Canada, are presented. Electron microprobe and $\mathrm{X}$-ray absorption near-edge structure (XANES) analysis found that $\mathrm{V}$ is present as $\mathrm{V}^{3+}$ substituted into magnetite and $\mathrm{V}^{3+}$ and $\mathrm{V}^{4+}$ substituted into titanite, both of which occur in the spilled Mount Polley tailings. Secondary $\mathrm{Fe}$ oxyhydroxides forming in inflow waters and on creek beds have V K-edge XANES spectra exhibiting E1/2 positions and pre-edge features consistent with the presence of $\mathrm{V}^{5+}$ species, suggesting sorption of this species on these secondary phases. PHREEQC modeling suggests that the stream waters mostly contain $\mathrm{V}^{5+}$ and the inflow and pore waters contain a mixture of $\mathrm{V}^{3+}$ and $\mathrm{V}^{5+}$. These data, and stream, inflow, and pore water chemical data, suggest that dissolution of $\mathrm{V}(\mathrm{III})$-bearing magnetite, $\mathrm{V}(\mathrm{III})$ - and $\mathrm{V}(\mathrm{IV})$-bearing titanite, $\mathrm{V}(\mathrm{V})$-bearing $\mathrm{Fe}(-\mathrm{Al}-\mathrm{Si}$ - $\mathrm{Mn}$ ) oxhydroxides, and V-bearing $\mathrm{Al}(\mathrm{OH})_{3}$ and/or clay minerals may have occurred. In the circumneutral $\mathrm{pH}$ environment of Hazeltine Creek, elevated $\mathrm{V}$ concentrations are likely naturally attenuated by formation of $\mathrm{V}(\mathrm{V})$-bearing secondary $\mathrm{Fe}$ oxyhydroxide, $\mathrm{Al}(\mathrm{OH})_{3}$, or clay mineral colloids, suggesting that the $\mathrm{V}$ is not bioavailable. A conceptual model describing the origin and fate of $\mathrm{V}$ in Hazeltine Creek that is applicable to other river systems is presented.

\section{INTRODUCTION}

Vanadium $(\mathrm{V})$ is a transition metal that is the 22nd most abundant in the Earth's crust ${ }^{1,2}$ and occurs naturally in four oxidation states [V(II), V(III), V(IV), and V(V)]. Although V is an essential element for humans and animals at low concentrations, ${ }^{3}$ the intake of high concentrations of $\mathrm{V}$ can be carcinogenic and toxic. ${ }^{4,5}$ Generally, $\mathrm{V}(\mathrm{V})$ is considered to be the most toxic of the $\mathrm{V}$ species because it can inhibit or replace phosphate. ${ }^{6,7}$ Vanadium is classed by the United Nations, U.S.

Received: November 12, 2018

Revised: $\quad$ March 1, 2019

Accepted: March 4, 2019

Published: March 4, 2019 


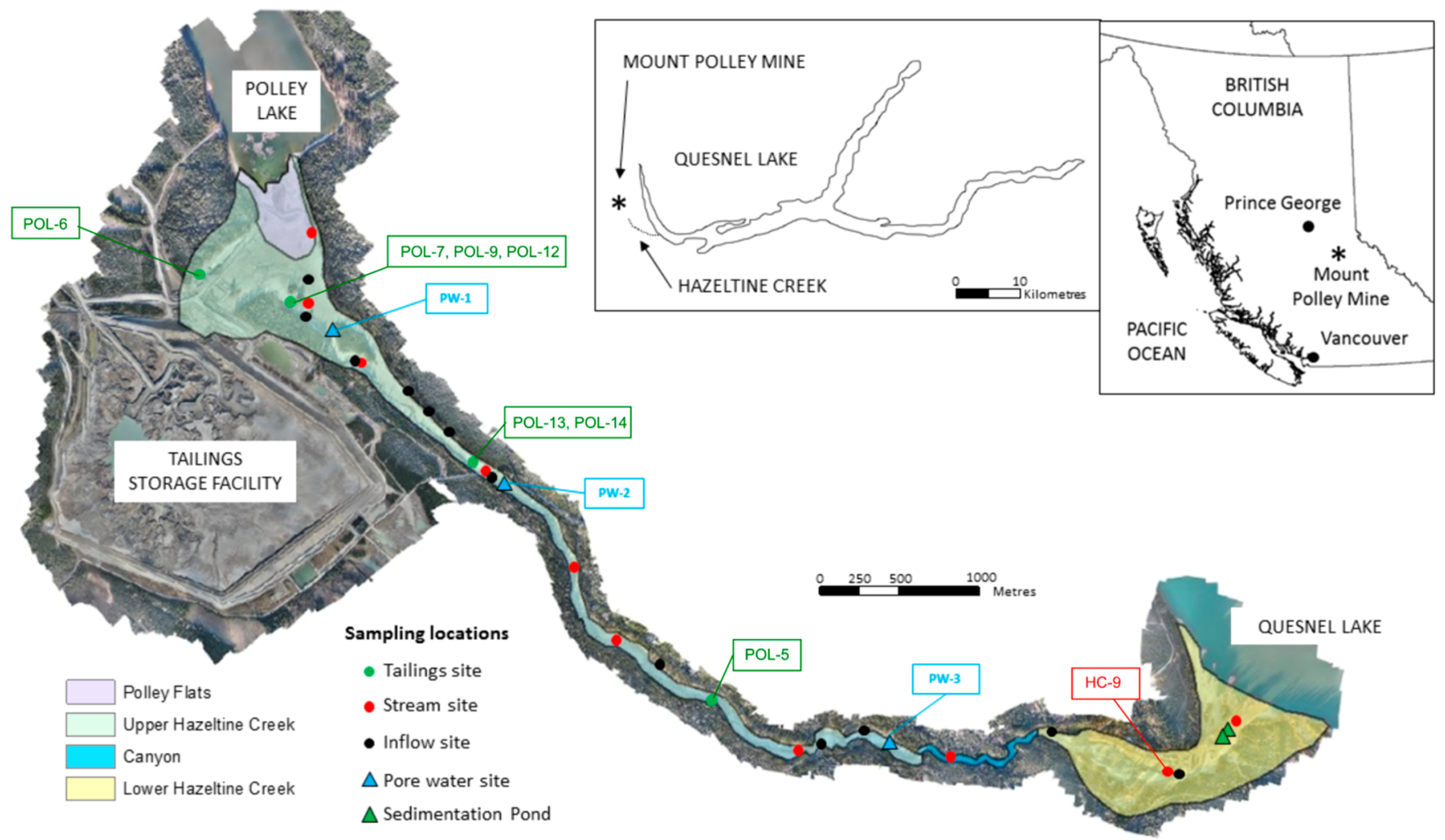

Figure 1. Location of the study area showing the Hazeltine Creek stream (HC-), inflow sample, pore water (PW-) and tailings, sediment, and Fe oxyhydroxide (POL-) sample sites for materials collected in 2014 and 2015. Labels shown are for those samples discussed in this work; sample locations for the remaining stream, inflow, and pore water samples are shown in ref 37.

Environmental Protection Agency, and Chinese Ministry of Environmental Protection as a priority environmental risk element. $^{2,8-10}$ In recognition of the potential toxicity of $\mathrm{V}$, Canada has set a Federal Water Quality Guideline of $120 \mu \mathrm{g} / \mathrm{L}$ for protection of aquatic life in freshwater, ${ }^{11}$ and Schiffer and Liber ${ }^{12}$ have suggested a more stringent chronic hazardous concentration endangering only $5 \%$ of species (HC5) of 50 $\mu \mathrm{g} / \mathrm{L}$ for Canadian freshwater organisms.

Humans can be exposed to vanadium mainly through inhalation and ingestion, potentially causing long-term respiratory and digestive problems, respectively. ${ }^{13}$ Aqueous vanadate $[\mathrm{V}(\mathrm{V})]$ can also be taken up in benthic organisms such as Hyalella azteca ${ }^{14}$ and have been shown to cause genotoxic and cytotoxic effects in higher plants. ${ }^{15}$ Vanadium can be distributed in water, soil, sediment, and air through the weathering of natural materials and through releases from anthropogenic activities, including the burning of fossil fuels, application of pesticides and phosphate fertilizers, steel, aerospace, and other industries, and mining. ${ }^{9,16,17}$ For example, mining activities have led to contamination of waters and soils with V (e.g., 76-208 $\mu \mathrm{g} / \mathrm{L}$ in groundwaters and 149-4800 $\mathrm{mg} / \mathrm{kg}$ in soils of the Panzhihua mining and smelting area in China ${ }^{18,19}$ ). There is, however, a lack of information about, and understanding of, the geochemical-mineralogical cycling of $\mathrm{V}$ in mining-affected environments, ${ }^{20}$ but these are required to determine health effects and to develop management and remediation schemes.

Mine tailings dam failures can rapidly add large amounts of V-bearing solid and liquid wastes to the fluvial environment. ${ }^{21}$ Globally, failures of mine tailings dams have significant impacts in the short (hours to months) and long term (years to centuries) on ecosystems and humans that live in affected catchments, through erosion, deposition of tailings sediment and fluids, and contamination of soil and water with potentially toxic metal and metalloid elements, and loss of life. ${ }^{22,23}$ The fourth August 2014 failure of the tailings storage facility (TSF) at Mount Polley, British Columbia, Canada, is the second largest by volume on record. ${ }^{23}$ Approximately $25 \mathrm{Mm}^{3}$ of material, comprising $7.3 \mathrm{Mm}^{3}$ of tailings solids, $10.6 \mathrm{Mm}^{3}$ of supernatant water, $6.5 \mathrm{Mm}^{3}$ of interstitial water, and $0.6 \mathrm{Mm}^{3}$ of tailings dam construction materials were discharged into the Quesnel River Watershed. ${ }^{23-25}$ The material flowed north into and plugged Polley Lake and then was diverted southeast into Hazeltine Creek for $9.5 \mathrm{~km}$. A significant proportion of the tailings and interstitial water $\left(18.6 \pm 1.4 \mathrm{M} \mathrm{m}^{3}\right)^{25}$ and eroded soils and vegetation ${ }^{26}$ were deposited into the West Basin of Quesnel Lake (Figure 1). Deposition of tailings (average $1 \mathrm{~m}$ thick, but up to $3.5 \mathrm{~m}$ thick in the upper part of the area nearest the TSF) also occurred within the Hazeltine Creek catchment up to $100 \mathrm{~m}$ from the channel, especially near Polley Lake and Lower Hazeltine Creek. ${ }^{25}$ Extensive cleanup has been undertaken since the spill (and since the sampling for this study was undertaken), comprising removal of most of the spilled tailings from, and restoration of, the catchment. This was aimed at restoring ecosystem habitats through the establishment of a new rock-lined channel, reducing remobilization of the remaining tailings and exposed natural sediments and decreasing turbidity,. 27,28

Mount Polley is a $\mathrm{Cu}-\mathrm{Au}$ porphyry deposit, and the tailings comprise mostly silicate minerals (feldspars, ferro-magnesian and $\mathrm{Ca}$-Ti-silicates, and muscovite), oxides such as magnetite and rutile, carbonates, $\mathrm{Cu}$ sulfides, and pyrite. Although the 
Mount Polley tailings have low sulfide (0.1-0.3 wt \%) and trace metal and metalloid concentrations ${ }^{29}$ relative to those of other tailings, ${ }^{22,30,31}$ they have elevated concentrations of $\mathrm{V}$ (86-295 mg/kg) compared to local background soils (40.2$\left.133 \mathrm{mg} / \mathrm{kg}^{27}\right)$. Vanadium was also initially identified, in addition to $\mathrm{Cu}, \mathrm{Se}$, and $\mathrm{Mo}$, as a contaminant of potential concern in Hazeltine Creek soils. ${ }^{32}$ The cycling of $\mathrm{Cu}$ in Hazeltine Creek has been previously examined in detail, $^{26,29,33-37}$ but detailed geochemical and mineralogical studies of $\mathrm{V}, \mathrm{Se}$, and Mo have not been conducted.

In this paper, we focus on $\mathrm{V}$ due to its high environmental risk potential ${ }^{2,8-10}$ and the relative lack of data on its behavior in mining-affected environments. ${ }^{20}$ We aim to understand the geochemical cycling of $\mathrm{V}$ in the Hazeltine Creek catchment and its implications for the origin, transport, fate, and potentially toxicity of $\mathrm{V}$ in other river systems. The objectives of the study are to determine (1) V concentrations and speciation in stream, inflow, and pore waters using aqueous composition data and PHREEQC modeling, (2) solid-phase V concentrations and speciation in the deposited tailings and secondary $\mathrm{Fe}$ oxyhydroxides using electron microprobe, automated mineralogy analysis, and X-ray absorption spectroscopy (XAS) analysis, and (3) the environmental origin, fate, and potential hazard of the deposition of V-bearing tailings in mining-affected catchments following tailings dam failures and remediation. We present, for the first time to the best of our knowledge for natural systems, evidence that dissolution of V-bearing magnetite and titanite may contribute to aqueous $\mathrm{V}$. The results will also inform restoration and management schemes for river systems receiving $\mathrm{V}$ from other natural and anthropogenic sources.

\section{MATERIALS AND METHODS}

Field Site. The Mount Polley porphyry $\mathrm{Cu}-\mathrm{Au} \operatorname{mine}^{38}$ is located in British Columbia, Canada, $275 \mathrm{~km}$ southeast of Prince George (Figure 1). Hazeltine Creek drains an area of $112 \mathrm{~km}^{2}$, including Polley Lake (Figure 1) and flows $9.5 \mathrm{~km}$ in a southeasterly direction before discharging into Quesnel Lake. Hazeltine Creek has an alkaline $\mathrm{pH}$ (average of 8.2 prior to the spill; ${ }^{39} \mathrm{pH} 7.0-9.3$ from July 30 to August 2, 2015 $5^{37}$ ). The catchment is underlain by Late Triassic alkali intrusions, including the porphyry $\mathrm{Cu}-\mathrm{Au}$ orebody, and by Mesozoic basaltic and andesitic volcanics, and glaciofluvial and glaciolacustrine deposits. ${ }^{38}$

Water Sampling, Analysis, and Speciation-Solubility Modeling. Details of water sampling analysis and quality control are presented in ref 37 and are summarized briefly here. In August 2015, samples were collected from 10 stream waters from Hazeltine Creek, 12 inflow waters seeping from riparian tailings into the creek, and three stream channel pore water sites collected at depths of 10 and $20 \mathrm{~cm}$ through deposited tailings, natural stream sediments, and bank materials (using a $3 / 8$ in. stainless steel piezometer and peristaltic pump). The piezometer design used in this study was developed by the U.S. Geological Survey and has been used extensively to sample trace metals in pore waters. Standard practice for operating the piezometer is to flush it with deionized water before and after pumping to ensure that the drive point itself is clean and not contaminated. Furthermore, it is unlikely that metal leaching would occur over the time scale of pore water pumping and sampling (2-3 $\mathrm{min})$. Thus, we believe that there was no contribution of $\mathrm{V}$ or other metals to the pore water samples. The sampling took place when spilled tailings were being excavated and removed from the creek valley, creek turbidity was high, and a new channel was being constructed. Thus, the results reported here could be considered to represent conditions that might be encountered during a spring freshet. ${ }^{34}$ The concentrations of total and filtered $(<0.45 \mu \mathrm{m})$ major $(\mathrm{Al}, \mathrm{Ca}, \mathrm{K}, \mathrm{Mg}, \mathrm{Na}$, and $\mathrm{Si}$ ) and trace elements (As, $\mathrm{Cd}, \mathrm{Cu}, \mathrm{Cr}, \mathrm{Fe}, \mathrm{Mo}, \mathrm{Mn}, \mathrm{Ni}, \mathrm{Pb}$, $\mathrm{Se}, \mathrm{V}$, and $\mathrm{Zn}$ ) were determined by inductively coupled plasma optical emission spectroscopy (Thermo Scientific iCAP 6500 Duo) and mass spectroscopy (Thermo X-series 1 ), respectively. Ion chromatography (Dionex ICS-2500) was used to determine filtered anion $\left(\mathrm{Cl}, \mathrm{F}\right.$, and $\left.\mathrm{SO}_{4}\right)$ concentrations. Equilibrium modeling, using the measured aqueous concentrations and other aqueous parameters of the Hazeltine Creek stream, inflow, and pore water samples, was carried out using the PHREEQC code and the minteq dat.v4 thermodynamic database distributed with the code. ${ }^{40,41}$ Alkalinity was estimated for the stream and inflow waters as bicarbonate by ion sum calculation (i.e., charge balance was forced with bicarbonate). We carried out calculations to check if the modeled $\mathrm{V}$ speciation and saturation indices were sensitive to bicarbonate activity using different $\mathrm{HCO}_{3}$ concentrations and found no significant differences in our results. Ferrihydrite and amorphous $\mathrm{Al}(\mathrm{OH})_{3}$ were allowed to precipitate during the equilibrium modeling, as the waters are not likely to be oversaturated with respect to these minerals.

Tailings, Sediment, and Fe Oxyhydroxide Sampling and XRF V Analysis. In August 2016, samples of deposited tailings and a secondary $\mathrm{Fe}$ oxyhydroxide sample deposit scraped from a seep draining a reprofiled stream bank (Table S4) were also collected in clean polyethylene bags. These were air-dried and stored at $4{ }^{\circ} \mathrm{C}$ until they were used. A proportion was crushed and pressed into powder pellets for $\mathrm{V}$ analysis by XRF (Bruker S4 Pioneer). Subsamples of deposited tailings [ST 09-02-01-140915 and WT 17-08-02-140912 (Table S4)] collected in 2014 following the dam failure by consultants of Mount Polley Mining Corp., and described by SNC-Lavalin Inc., ${ }^{26}$ were donated by the mine for comparison to samples collected by the authors.

Electron Microprobe and Automated Mineralogy Analysis. Polished blocks of all solid samples were examined with a Jeol 8100 Superprobe (WDS) with an Oxford Instrument Inca System (EDS). Spot analyses and X-ray chemical mapping were carried out by collecting energy data between 0 and $20 \mathrm{eV}$ using an accelerating voltage of $15 \mathrm{kV}$, a current of $2.5 \mathrm{~mA}$, and a spot size of $1 \mu \mathrm{m}$. The analyses were calibrated using a ZAF (atomic number, absorption, fluorescence) matrix correction with standards of oxides and Specpure metals. To quantify and further characterize and quantify the bulk mineralogy and those minerals identified with the Superprobe as containing V, the polished blocks were investigated using a Mineral Liberation Analysis automated mineralogy system on a FEI Quanta 650 FEG ESEM instrument equipped with twin Bruker XFlash EDS detectors at Queen's University. Spectra were collected at $25 \mathrm{kV}$, with a minimum of 2000 counts per analysis, recording $\geq 250000 \mathrm{X}$ ray spectra on each sample to calculate total area percentages of each mineral detected and then a further 800000 spectra at higher-resolution searching and targeting V-bearing minerals at fine detail.

X-ray Absorption Spectroscopy (XAS) Analysis. Microfocus XANES V K-edge spectra $(5465 \mathrm{eV})$ for individual magnetite, titanite, and Fe oxyhydroxide grains were collected 
on beamline I18 at the Diamond Light Source operating at 3 $\mathrm{GeV}$ with a typical current of $300 \mathrm{~mA}$, using a nitrogen-cooled $\mathrm{Si}(111)$ double-crystal monochromator and focusing optics. Kirkpatrick-Baez mirrors were used to produce a focused beam with a diameter of $3 \mu \mathrm{m}$ at the sample. For samples and standards $\left[\mathrm{V}\right.$ metal, $\mathrm{V}_{2} \mathrm{O}_{3}, \mathrm{VO}_{2}, \mathrm{~V}_{2} \mathrm{O}_{5}$, and $\mathrm{V}(\mathrm{V})$ sorbed to $\mathrm{FeOOH}$ (see the Supporting Information for the preparation method)], K-edge spectra were collected in fluorescence mode at room temperature $(\sim 295 \mathrm{~K})$ using a four-element solid state $\mathrm{Si}$ detector. Because we analyzed V-bearing titanite, we checked that the $\mathrm{V} \mathrm{K} \alpha$ emission line could be resolved, despite its overlap with the $\mathrm{Ti} \mathrm{K} \beta$ emission line. On beamline I18, the $\mathrm{Ti} \mathrm{K} \alpha$ emission at $\sim 4510 \mathrm{eV}$ can be resolved in XRF detectors from the $\mathrm{V} \mathrm{K} \alpha$ emission at $\sim 4950 \mathrm{eV}(250-300 \mathrm{eV}$ separation is required for effective windowing of I18's XRF detectors). The lower-intensity $\mathrm{Ti}$ K- $\beta$ emission at $4932 \mathrm{eV}$ cannot be resolved by any XRF detector, but the binding energy of the $\mathrm{V} \mathrm{K}$ edge $(5465 \mathrm{eV})$ is $\sim 500 \mathrm{eV}$ above the Ti K edge $(4966 \mathrm{eV})$. Therefore, interference of the Ti K- $\beta$ XAS spectra and V K- $\alpha$ XANES spectra was minimal and limited to long wavelength, low-amplitude EXAFS oscillations, by 4950 eV Ti K-edge oscillations that would be not be apparent in VXANES. After the XANES data had been collected, multiple scans were then averaged to improve the signal-to-noise ratio using Athena version 0.8.061. ${ }^{42}$ XANES spectral absorption data were also normalized in Athena over the full data range and plotted from approximately -15 to $30 \mathrm{eV}$ relative to the edge position with no correction required for drift in $E_{0}$. Vanadium data were calibrated using $E_{0}$ measured from thin metal foils inserted downstream of the samples and measured simultaneously. The $\mathrm{V}$ metal $\mathrm{K}$ edge was detected, and the $E_{0}$ position did not drift between spectra. The $\mathrm{V}$ pre-edge peak energy was determined by calculation of the area-normalized centroid energy position (i.e., the peak intensity is normalized to the height of the main $\mathrm{V} \mathrm{K}$-edge step on the $y$-axis of the resultant graph, plotted against the area-normalized pre-edge centroid peak energy position on the $x$-axis) following the method of Chaurand et al., ${ }^{43}$ and used previously for solidphase $\mathrm{V}$ speciation in bauxite residue. ${ }^{44}$

\section{RESULTS AND DISCUSSION}

Aqueous V Geochemistry and Speciation. Filtered V concentrations (mean of $9 \mu \mathrm{g} / \mathrm{L}$, range of $7-12 \mu \mathrm{g} / \mathrm{L}$ ) in the Hazeltine Creek stream waters were slightly elevated compared to pre-event mean concentrations $\left(1 \mu \mathrm{g} / \mathrm{L}^{29}\right)$, higher than mean global filtered river concentrations $\left(0.71 \mu \mathrm{g} / \mathrm{L}^{45}\right)$ but lower than chronic hazardous concentrations recently identified for freshwater organisms. ${ }^{12}$

Overall, filtered $\mathrm{V}$ concentrations declined with the distance downstream of the Polley Lake weir (Figure 2). Filtered V concentrations in the stream waters were generally lower than those of the inflows seeping from tailings (mean of $17 \mu \mathrm{g} / \mathrm{L}$, range of $4-41 \mu \mathrm{g} / \mathrm{L}$ ), but the inflow waters do not appear to have affected $\mathrm{V}$ concentrations downstream, likely because of their low volumes and flow rates (Figure 2). Unfiltered V concentrations in stream (mean of $15 \mu \mathrm{g} / \mathrm{L}$, range of $11-21$ $\mu \mathrm{g} / \mathrm{L}$ ) and inflow waters (mean of $59 \mu \mathrm{g} / \mathrm{L}$, range of $4-303$ $\mu \mathrm{g} / \mathrm{L}^{1}$ ) were either similar to (within $7 \mu \mathrm{g} / \mathrm{L} ; 62 \%$ of samples) or higher than $(\leq 278 \mu \mathrm{g} / \mathrm{L} ; 38 \%$ of samples) their respective filtered concentrations. ${ }^{37}$ Unfiltered $\mathrm{V}$ concentrations were highest in the inflow waters in the upper part of the catchment within approximately $2000 \mathrm{~m}$ of the Polley Lake weir (Figure 2).

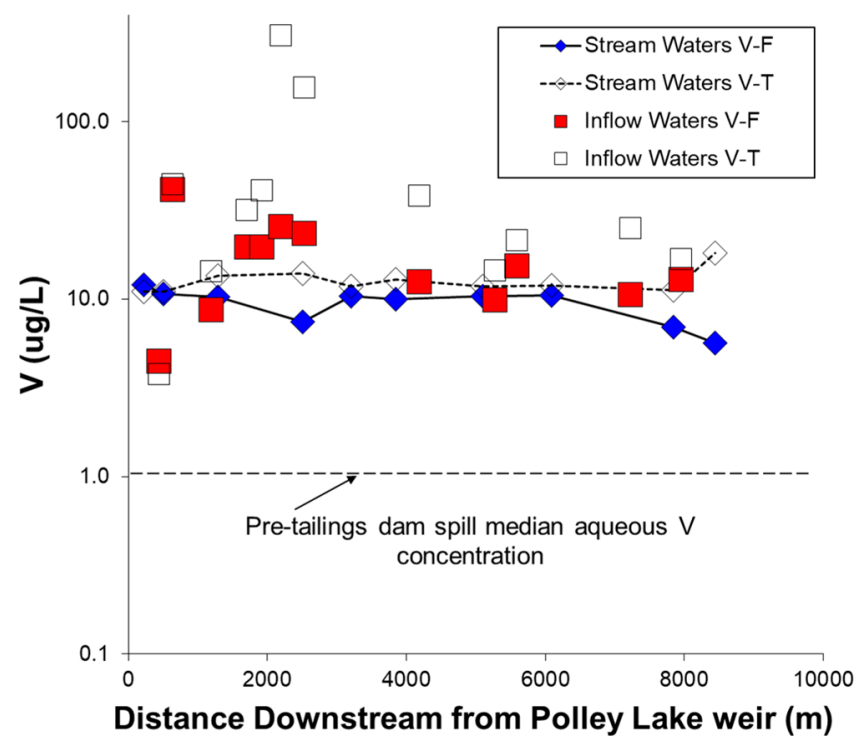

Figure 2. Spatial profile of the Hazeltine Creek stream and inflow filtered (V-F) and unfiltered (V-T) V concentrations. Samples were collected in August 2015. The pretailings dam spill median V concentration of $1 \mu \mathrm{g} / \mathrm{L}^{29}$ is shown for reference.

Filtered V concentrations in the Hazeltine Creek stream waters at $0 \mathrm{~cm}$ in the sampled profiles $(8-11 \mu \mathrm{g} / \mathrm{L})$ were similar to those of the other stream waters collected. At a depth of $10 \mathrm{~cm}$, all filtered pore water $\mathrm{V}$ concentrations peaked [132, 1200, and $53 \mu \mathrm{g} / \mathrm{L}$ for PW-1, PW-2, and PW-3, respectively (Figure 3)], but concentrations declined at a depth of $20 \mathrm{~cm}$ (83, 231, and $43 \mu \mathrm{g} / \mathrm{L}$ for PW-1, PW-2, and PW-3, respectively). Peaks in filtered $\mathrm{V}$ concentrations at a depth of $10 \mathrm{~cm}$ coincide with peaks in filtered $\mathrm{Al}, \mathrm{As}, \mathrm{Ca}, \mathrm{Cu}, \mathrm{Fe}, \mathrm{K}, \mathrm{Mg}$, $\mathrm{Mn}, \mathrm{Ni}, \mathrm{Zn}$, and $\mathrm{Si}$ concentrations and declines in ORP and $\mathrm{pH}$ (Figure 3). The fact that $\mathrm{PW}-2$ has $\mathrm{V}$ concentrations higher than those in PW-1 and PW-3 might be due to its position at the downstream end of upper Hazeltine Creek (Figure 1), where the greatest amount of spilled tailings was deposited following the tailings dam failure and remained at the time of sampling in August 2015. ${ }^{37}$

Filtered $\mathrm{V}$ concentrations for most of the pore waters are positively correlated with filtered concentrations of $\mathrm{Fe}, \mathrm{Al}, \mathrm{Cr}$, $\mathrm{Ni}$, and $\mathrm{Si}$ and slightly positively but more flatly correlated with filtered $\mathrm{Ca}$ concentrations (Figure 4). By contrast, filtered concentrations of inflow waters are poorly correlated with $\mathrm{Fe}$, $\mathrm{Al}$, and $\mathrm{Ni}$ concentrations but well correlated with $\mathrm{Si}, \mathrm{Ca}$, and $\mathrm{Cr}$, together with some of the pore water samples.

The PHREEQC modeling suggested that no minerals with $\mathrm{V}$ as a major component were oversaturated in any of the Hazeltine Creek waters (Table S1). Calcite, diaspore, and gibbsite were predicted to be slightly oversaturated in many of the samples (Table S1). Pentavalent V was predicted to form $100 \%$ of all of the aqueous V species in all but one (HC9) of the stream waters. By contrast, the inflow and pore waters are modeled to contain varying amounts of $\mathrm{V}(\mathrm{III})$ and $\mathrm{V}(\mathrm{V})$ (Table S2). V(III) is modeled to dominate in some of the inflow waters and in the pore waters at a depth of $20 \mathrm{~cm}$, and $\mathrm{V}(\mathrm{V})$ is predicted to dominate in the majority of the inflow waters and in the pore waters at depths of 0 and $10 \mathrm{~m}$ (Table S2). The modeling suggests that $\mathrm{HVO}_{4}{ }^{2-}$ was the dominant species $(50-86 \%)$ in all but one (HC9) of the stream waters, with smaller amounts of $\mathrm{H}_{2} \mathrm{VO}_{4}^{-}$[14-50\% (Table S3)]. The 

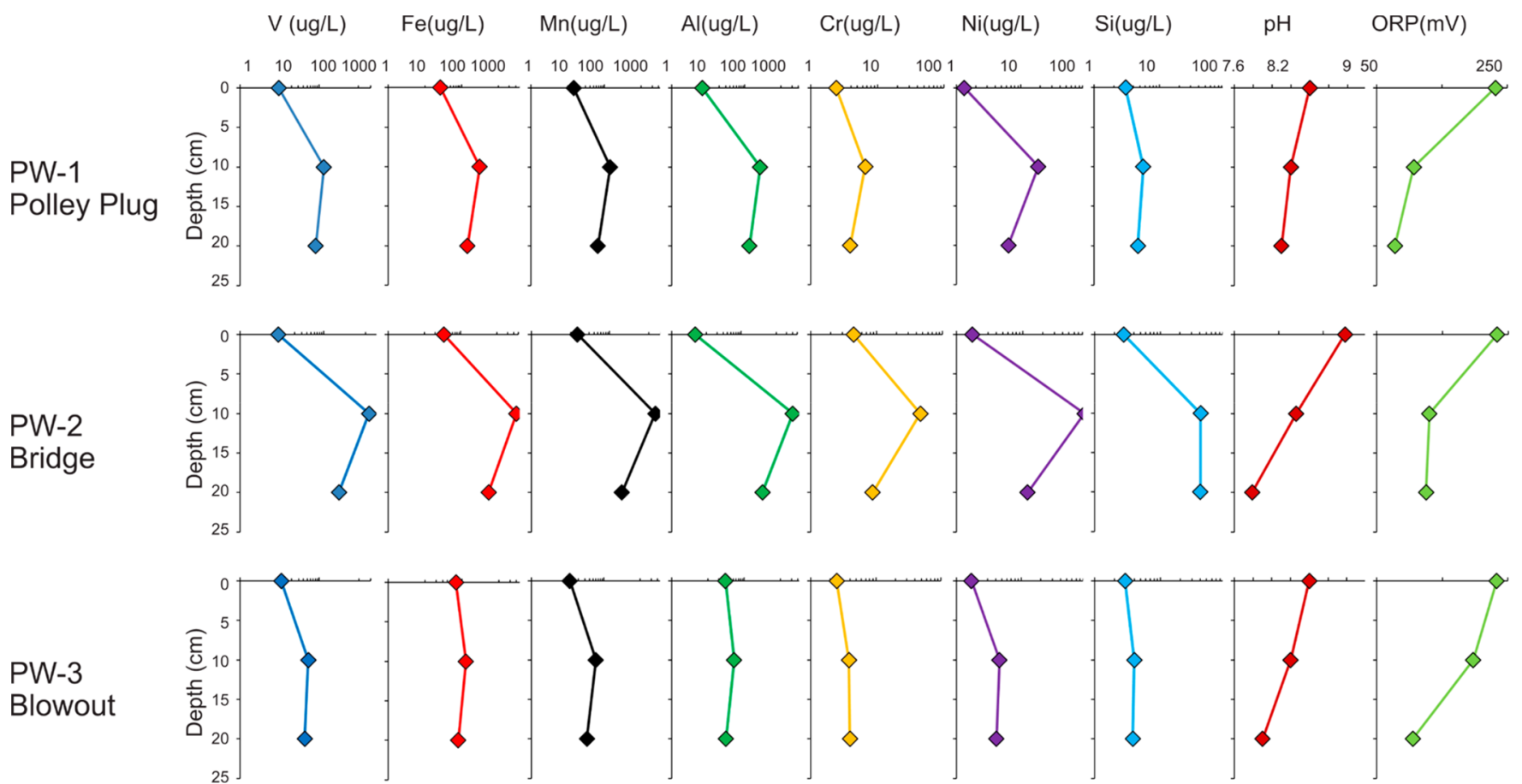

Figure 3. Geochemical profiles for pore water profiles PW-1, PW-2, and PW-3.

inflow and pore waters have relatively low calculated proportions of $\mathrm{HVO}_{4}^{2-}$ (inflow, 23-63\%; pore, 2146\%) and relatively high proportions of $\mathrm{H}_{2} \mathrm{VO}_{4}^{-}$[inflow, 37-77\%; pore, 54-77\% (Table S3)]. The highest $\mathrm{V}$ concentrations recorded in this study occur in inflow and pore waters at $\mathrm{pH}<8.1-8.3$, which is the equilibrium point between the weak acid and conjugate base $\left(\mathrm{p} K_{\mathrm{a}}\right)(\mathrm{pH} 8.1-8.3)$ between $\mathrm{HVO}_{4}{ }^{2-}$ and $\mathrm{H}_{2} \mathrm{VO}_{4}^{-}$at $25^{\circ} \mathrm{C}$.

We did not measure DOC concentrations and thus were not able to develop a V-organic complexation model. However, we acknowledge that $\mathrm{V}$ is known to bind with DOC in the form of humic acids and EDTA in aquatic environments ${ }^{47-49}$ and, therefore, that DOC may have played a role in $\mathrm{V}$ cycling in the Hazeltine Creek catchment.

Solid-Phase V Geochemistry and Mineralogy. Concentrations of $\mathrm{V}$ in the study samples ranged from 51 to 231 $\mathrm{mg} / \mathrm{kg}$ (Table S4), which are mostly within the range for Mount Polley tailings collected in $2014 .^{26}$ The V concentrations are lower than concentrations reported for some mine wastes (e.g., 860-963 mg/kg for red mud from the 2010 Ajka, Hungary, alumina processing repository failure ${ }^{44}$ ) but are within the same range as others (e.g., $135 \mathrm{mg} / \mathrm{kg}$ for abandoned $\mathrm{Au}$ mine tailings in Nova Scotia, Canada; ${ }^{50} 40.7$ $\mathrm{mg} / \mathrm{kg}$ for polysulfide tailings in Boliden, Sweden $\left.{ }^{51}\right)$. The spilled tailings [samples POL-5-7 and POL-9 (Table S5)] are dominated by orthoclase and albite (both $32-41$ area \%), with smaller amounts of hornblende/augite (3.9-5.1 area \%), epidote (3.5-4.9 area \%), muscovite (3.2-3.8 area \%), plagioclase (1.6-2.5 area \%), quartz (1.3-2.4 area \%), and chlorite (1.3-1.5 area \%), similar to proportions found by Kennedy et al. ${ }^{52}$ The magnetite abundance is ascribed to Fe oxides in the automated mineralogy analysis, forming 1.2-3.1 area $\%$ of the total mineralogy, while titanite forms $0.5-1.7$ area \%. A Cu-bearing $\mathrm{Fe}$ oxide phase containing $>0.1 \mathrm{wt} \% \mathrm{Cu}$ was added to the automated mineralogy library, ${ }^{34}$ and this phase forms $0.5-2.3$ area $\%$ of the tailings. The remaining samples [POL-12-14 (Table S5)] contain higher proportions of quartz (20-50 area \%), suggesting dilution by catchment soils.

Magnetite and titanite in the Mount Polley tailings both contain V (Figure 5), but no other tailings minerals were found to contain $\mathrm{V}$ at the detection limit of the microprobe (0.001 wt $\%)$. Average $\mathrm{V}$ concentrations for 11 magnetite grains are 0.28 wt \% (range of $0.16-0.37 \mathrm{wt} \%$ ) and for 14 titanite grains are 0.25 wt $\%(0.14-0.35$ wt \%). The latter are within the same order of magnitude as those determined by Celis ${ }^{53}$ for 57 titanite grains from the Mount Polley deposit (mean of $0.15 \mathrm{wt}$ $\% \mathrm{~V}$, range of $0.06-0.29 \mathrm{wt} \% \mathrm{~V})$. The magnetite also contains trace amounts of $\mathrm{Si}$ (mean of $0.045 \mathrm{wt} \%$ ), and magnetite and titanite contain trace concentrations of $\mathrm{Al}(0.045$ and $0.037 \mathrm{wt}$ $\%$, respectively), $\mathrm{Cr}$ (0.042 and 0.001 wt \%, respectively), and $\mathrm{Mn}$ ( 0.13 and 0.042 wt \%, respectively). Vanadium concentrations in the $\mathrm{Fe}$ oxyhydroxide collected from a seep draining a reprofiled stream bank are low, at or below the limit of detection of the microprobe ( $\leq 0.001$ wt $\% \mathrm{~V} ; 10$ grains).

Vanadium XANES Analysis. Charaund et al. ${ }^{43}$ proposed an elegant system for interpreting V K-edge XANES spectra based on the detail observation of pre-edge peak intensity and energy position. In this system, data are described in terms of variation in both coordination symmetry and valence state. Data are provided from multiple $\mathrm{V}(\mathrm{V})$ standards as $\mathrm{V}$ K-edge XANES is sensitive to changes in both valence and the mode of structural incorporation [e.g., $\mathrm{V}(\mathrm{V})$ on $\mathrm{FeOOH}$ is tetrahedral, and $\mathrm{V}(\mathrm{V})$ in $\mathrm{V}_{2} \mathrm{O}_{5}$ is square pyramidal ${ }^{54-56}$. The multiple $\mathrm{V}(\mathrm{V})$ standards are therefore desirable to investigate the mode of $\mathrm{V}$ occurrence in samples. When the Mount Polly magnetite and titanite data are plotted in this scheme, the sample data are plotted between the octahedral $\mathrm{V}^{3+}$ and $\mathrm{V}^{4+}$ standards. The magnetite samples appear to contain primarily $\mathrm{V}^{3+}$, suggesting incorporation of $\mathrm{V}^{3+}$ via substitution for octahedral $\mathrm{Fe}^{3+}$ within the structure. This is consistent with other studies of magnetite, ${ }^{57-59}$ although Balan 

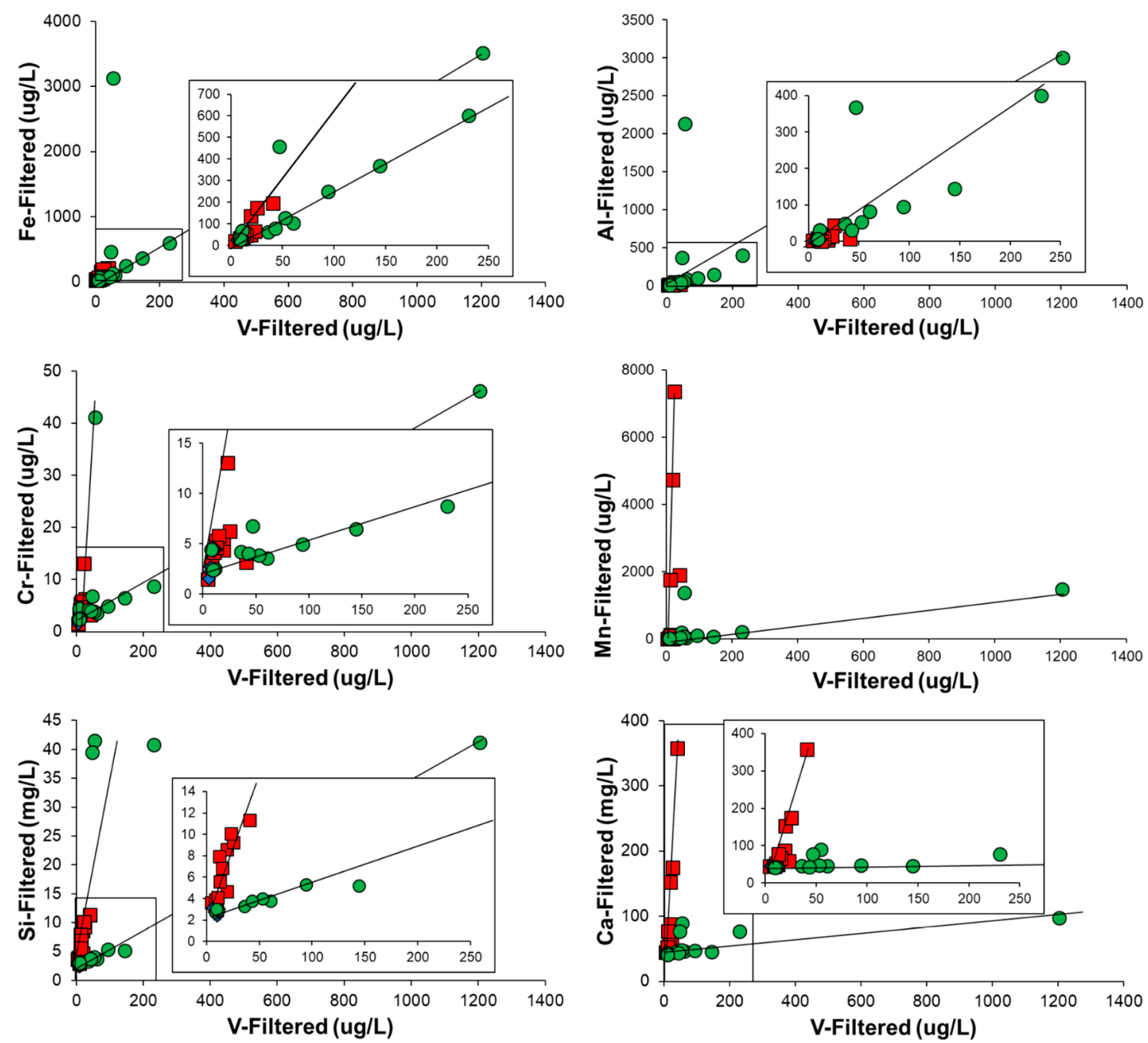

Inflow Waters

$\diamond$ Stream Waters

oPore Waters

Figure 4. $X-Y$ plots showing the relationship between filtered $\mathrm{V}$ and other filtered element concentrations in stream, inflow, and pore waters. Stream water sample concentrations are mostly $<10 \mu \mathrm{g} / \mathrm{L}$ and so are masked by the inflow and pore waters. Trends shown for the inflow waters (red squares) and for most of the pore water data (green circles).

et al. ${ }^{58}$ also found minor $(<10 \%) \mathrm{V}(\mathrm{IV})$ occupying octahedral sites. The Mount Polley titanite $\mathrm{V}$ is plotted between octahedrally coordinated $\mathrm{V}^{3+}$ and $\mathrm{V}^{4+}$ (Figure 6), suggesting that it most likely substituting for octahedrally coordinated $\mathrm{Fe}^{3+}, \mathrm{Al}^{3+}$, or $\mathrm{Ti}^{4+}$ in the mineral structure. Celis ${ }^{53}$ found that Mount Polley titanite contained almost equal concentrations of $\mathrm{Al}$ and $\mathrm{Fe}$, substantiating the possibility of $\mathrm{V}^{3+}$ substitution for $\mathrm{Fe}^{3+}$ and $\mathrm{Al}^{3+}$. Pan and Fleet ${ }^{60}$ also reported that octahedrally coordinated $\mathrm{V}^{3+}$ and $\mathrm{V}^{4+}$ had radii $(0.64$ and $0.58 \AA$, respectively) similar to that of octahedrally coordinated $\mathrm{Al}^{3+}$ $\left(0.535 \AA^{61}\right)$ and could therefore substitute for the latter within the vanadian titanite of the Hemlo gold deposit.

The V-bearing iron oxyhydroxide sample is plotted between $\mathrm{V}^{4+}\left(\mathrm{O}_{\mathrm{h}}\right)$ and the $\mathrm{V}^{5+}$ absorbed to $\mathrm{FeOOH}$ standards. It is possible that $\mathrm{V}$ in these samples is present as a mixture between the primary $\mathrm{V}^{4+}$ and $\mathrm{V}^{5+}$ in absorption complexes on hydrous iron oxyhydroxides. However, adsorbed $\mathrm{V}^{4+}$ does not persist in oxygenated environments as it is readily oxidized to
$\mathrm{V}^{5+62}$ and most of the scientific literature reports the strong affinity of $\mathrm{Fe}$ oxyhydroxides such as goethite and ferrihydrite for $\mathrm{V}^{5+}{ }^{5463-65}$ Kaur et al. ${ }^{65}$ attempted to make samples of $\mathrm{V}(\mathrm{III})$-containing goethite but found that some oxidation occurred and that V(III), V(IV), and V(V) were also present. The resultant XANES spectra are intermediate between those of V(III) and V(V), similar to our spectra (Figure 6). Kaur et al. ${ }^{65}$ also provided data that suggested that oxidized $\mathrm{V}$ was not readily incorporated in the goethite and therefore are likely resent as adsorbed $\mathrm{V}(\mathrm{V})$ that was more easily removed by protons than more reduced forms.

Vanadium Cycling in Hazeltine Creek following the Mount Polley Tailings Dam Failure and Remediation. V(III)-bearing magnetite and V(III)- and/or V(IV)-bearing titanite (Figures 5 and 6) were deposited within remobilized tailings and together with a large number of uprooted trees in the Hazeltine Creek catchment following the 2014 Mount Polley dam failure. It is also possible that smaller amounts of 


\section{Tailings}
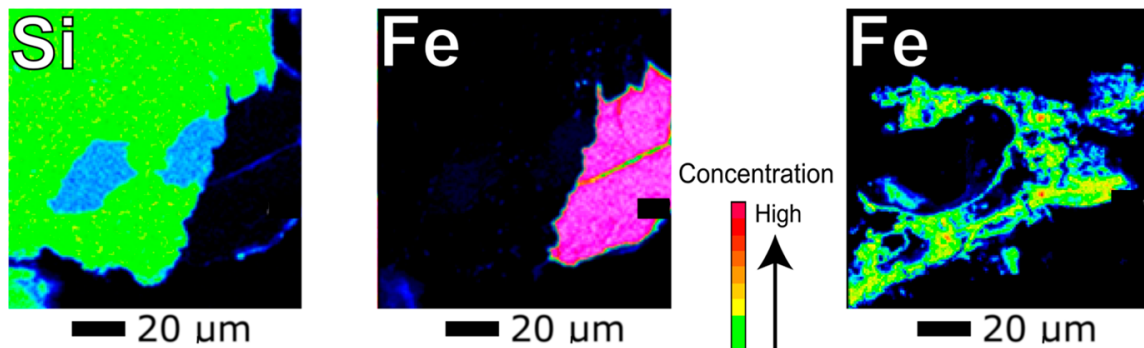

$20 \mu \mathrm{m}$

\section{Fe oxyhyd}
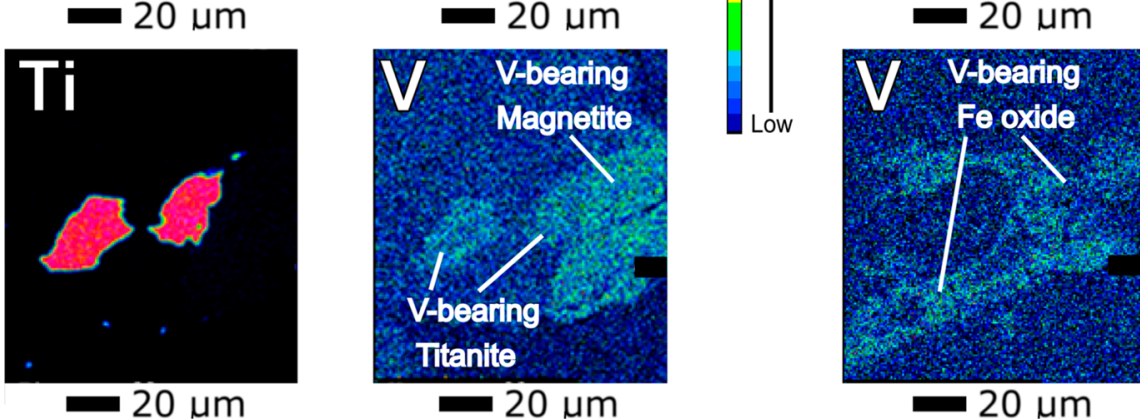

Figure 5. Electron microprobe X-ray maps showing V-bearing titanite and magnetite in Mount Polley tailings (POL-5) and V-bearing Fe oxide in the Fe oxyhydroxide (Fe oxyhyd) (POL-13).

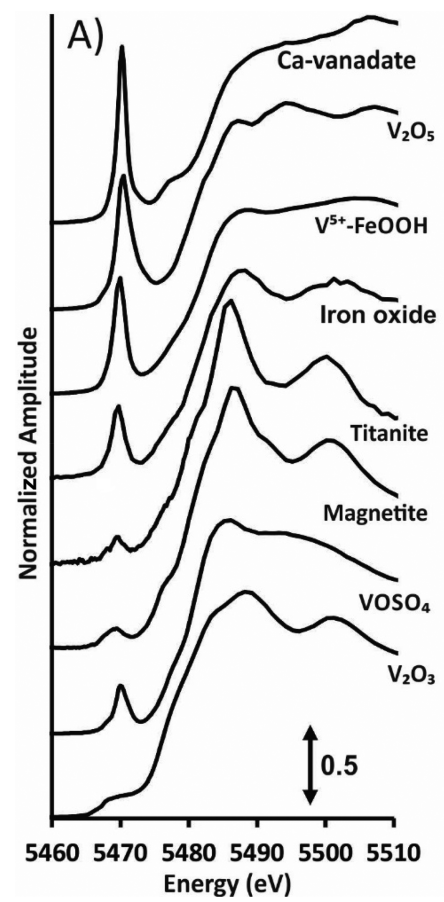

B)

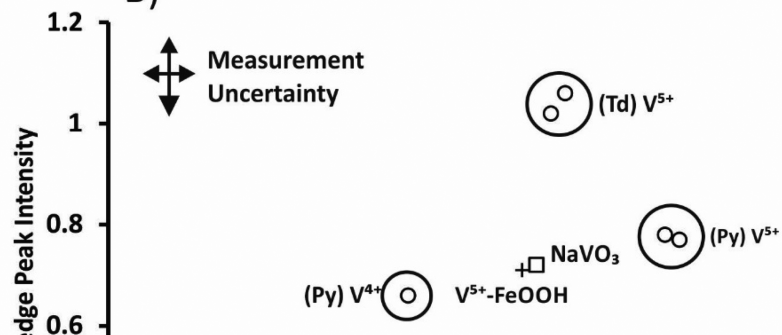

V-FeOxide

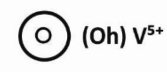

(0) $\left(\right.$ Oh) v $\mathrm{v}^{4+}$

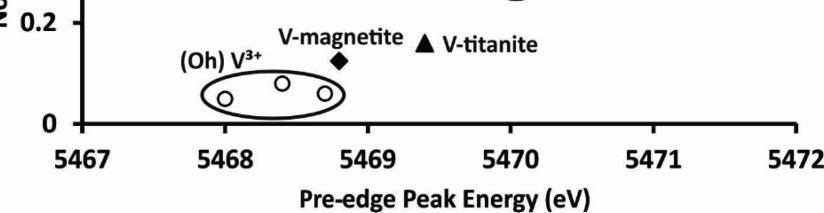

Figure 6. (a) K-Edge XANES spectra collected from Mount Polly mineral samples and selected V-containing standards. (b) Plot of pre-edge intensity vs pre-edge peak energy derived from V K-edge XANES spectra. V standard data from Hobson et al., ${ }^{72}$ Burke et al., $^{21,44} \mathrm{Charaund}$ et al., ${ }^{43}$ Bronkema and Bell, ${ }^{73}$ and Wong et al. ${ }^{74}(\mathrm{Td}),(\mathrm{Py})$, and $(\mathrm{Oh})$ refer to tetrahedral, square pyramidal, and octahedral coordination, respectively.

these minerals occurred within Hazeltine Creek channel and floodplain sediments and soils prior to the failure, given the relatively high $\mathrm{V}$ concentrations of some background soils. ${ }^{26} \mathrm{~A}$ year after the tailings dam failure, high filtered concentrations of $\mathrm{V}$ in pore waters occurring at depths of $20 \mathrm{~cm}$ and especially $10 \mathrm{~cm}$ in Hazeltine Creek coincide with peak concentrations of $\mathrm{Al}, \mathrm{As}, \mathrm{Ca}, \mathrm{Cu}, \mathrm{Fe}, \mathrm{K}, \mathrm{Mg}, \mathrm{Mn}, \mathrm{Ni}, \mathrm{Zn}$, and $\mathrm{Si}$ and declines in ORP and $\mathrm{pH}$ (Figure 3). It is possible that these high concentrations reflect those in initial tailings dam pore waters transported with the spilled tailings, but this is unlikely for the following reasons. First, most of the tailings and interstitial water went into Quesnel Lake rather than Hazeltine Creek. ${ }^{25}$ Second, we sampled in a very disturbed mixed river sediment rather than undisturbed layers of tailings. Third, we sampled a year after the spill, and the nature of the channel (high gradient, gravelly substrate) encouraged flushing by hyporheic exchange. Therefore, we propose that the high filtered $\mathrm{V}$ concentrations at depths of 10 and $20 \mathrm{~cm}$ arose from dissolution of $\mathrm{V}$-bearing phases containing these elements just below the water-sediment interface. ${ }^{66}$ Positive trends 
between concentrations of $\mathrm{V}$ and those of $\mathrm{Al}, \mathrm{Fe}, \mathrm{Cr}, \mathrm{Mn}$, and $\mathrm{Si}$ (Figure 4) suggest that one of the phases undergoing such dissolution could be the Mount Polley magnetite that incorporates these elements. The dissolution of vanadium titano-magnetite with similar concentrations of $\mathrm{V}$ ( $0.28 \mathrm{wt} \%)$ has been demonstrated experimentally by $\mathrm{Hu}$ et al., ${ }^{10}$ who showed that $\mathrm{V}$ is released from magnetite between $\mathrm{pH} 5.9$ and 8.8 under dissolved $\mathrm{O}_{2}$ concentrations ranging from $5 \%$ to $80 \%$. Other possibilities for phases undergoing dissolution to produce these positive trends could be V-bearing clay minerals, $\mathrm{Al}(\mathrm{OH})_{3}$, or $\mathrm{Fe}-\mathrm{Al}-\mathrm{Mn}-\mathrm{Si}$ oxyhydroxides whose $\mathrm{V}$ concentrations were below detection limits of our microprobe analysis and were small enough to pass through the $0.45 \mu \mathrm{m}$ filter.

Vanadium concentrations in inflow waters are mostly lower than those in pore waters; those of $\leq 50 \mu \mathrm{g} / \mathrm{L}$ correlate well with $\mathrm{Ca}, \mathrm{Si}, \mathrm{Fe}$, and $\mathrm{Al}$, while those of $\leq 25 \mu \mathrm{g} / \mathrm{L}$ correlate with $\mathrm{Cr}$ and $\mathrm{Mn}$ (Figure 4). The released $\mathrm{Ca}$ and $\mathrm{Si}$ can be attributed to the weathering of epidote or feldspar that are present in the tailings, and that of $\mathrm{Ca}, \mathrm{Si}, \mathrm{Fe}$, and $\mathrm{Al}$ to the weathering of hornblende (Table S5), but none of these minerals were found to contain V. Ca and $\mathrm{Si}$ are two of the major components of titanite, and Mount Polley titanites contain trace amounts of $\mathrm{V}, \mathrm{Fe}, \mathrm{Al}, \mathrm{Cr}$, and $\mathrm{Mn}$. It is proposed that titanite weathering in the tailings piles from which the inflows emanate is responsible for these trends and modest enrichments in V. Although they did not analyze for V, Tilley and Eggleton ${ }^{67}$ have shown that titanite can weather, likely under supergene conditions, to beidellite and anatase at neutral $\mathrm{pH}$, resulting in the loss of all of the Ca but retention of $\mathrm{Ti}$. The reason for the different $\mathrm{V}$ trends shown by the inflows and pore waters (Figure 4) is unknown but may be related to different proportions of these minerals in the spilled tailings.

Positive saturation indices for ferrihydrite and goethite (Table S1), the presence of Fe oxyhydroxides forming along the inflow waters, and the sampled V-bearing Fe oxyhydroxide [POL-13 (Table S5, Figure S3, and Figure 5)] show that some of the mobilized $\mathrm{V}$ is taken up by secondary Fe precipitates. Iron oxyhydroxides were observed in 2015 at the sedimentwater interface in Hazeltine Creek, especially in the riparian area downstream of the second gorge where the gradient shallowed and the valley widened [near HC-9 (Figure 1)]. These data and the declines in $\mathrm{Fe}$ concentrations in the Hazeltine Creek stream waters at $0 \mathrm{~cm}$ in the depth profiles collected (Figure 3) suggest that the high-Fe pore waters at a depth of $10 \mathrm{~cm}$ were attenuated by diffusion of aqueous $\mathrm{V}$ and $\mathrm{Fe}$ and/or by precipitation of $\mathrm{Fe}$ oxyhydroxides at this interface. The $\mathrm{V}$ in these $\mathrm{Fe}$ phases is most likely to be $\mathrm{V}(\mathrm{V})$, given the dominance of this species in the stream waters, in most of the inflow waters, and in the pore waters at depths of 0 and $10 \mathrm{~cm}$ in the PHREEQC (Table S2) and in the XANES modeling (Figure 6). The fact that filtered $\mathrm{V}$ concentrations for samples at $\mathrm{pH} 7.5-8.3$ are higher than those at $\mathrm{pH}>8.3$ (Figure $\mathrm{S} 1$ ) is consistent with experimental studies. Dzombak and Morel $^{68}$ and Naeem et al. ${ }^{8}$ demonstrated that the level of sorption of $\mathrm{V}$ to $\mathrm{Fe}$ oxides and hydroxides was highest between $\mathrm{pH} \sim 3.0$ and 3.5 and then decreased as $\mathrm{pH}$ increased from 4 to 11.6. Naeem et al. ${ }^{8}$ attributed this decrease to competition between $\mathrm{OH}$ - and aqueous $\mathrm{V}$ anions for $\mathrm{Fe}$ oxide/hydroxide surface binding sites. Similarly, positive saturation indices for the $\mathrm{Al}$ oxyhydroxide diaspore and $\mathrm{Al}$ hydroxide gibbsite and positive trends among total $\mathrm{Al}, \mathrm{Si}$, and $\mathrm{V}$ concentrations (Figure S2) also suggest that the formation of secondary phases such as (Al-Si-bearing) Fe oxyhydroxides, $\mathrm{Al}$ oxyhydroxides and hydroxides, or clay minerals (see above) may attenuate aqueous $\mathrm{V}$ concentrations that show a decline downstream in Hazeltine Creek (Figure 2).

The association of $\mathrm{V}$ with $\mathrm{Fe}$ oxyhydroxides has been observed for streams throughout Sweden affected by natural and anthropogenic inputs of $\mathrm{V},{ }^{69}$ with other studies showing that considerable $\mathrm{V}$ transport occurs in the colloidal phase. ${ }^{70}$ Concentrations of total $\mathrm{V}$ in Hazeltine Creek are higher than those of filtered V (Figure 2), and apart from the data from three inflow water samples, total $\mathrm{Fe}, \mathrm{Al}$, and $\mathrm{Si}$ concentrations correlate well with total $\mathrm{V}$ concentrations (Figure S2), suggesting that fine particulate transport of $\mathrm{V}$ is significant in the catchment.

The significance of the Mount Polley tailings spill with respect to water quality and $\mathrm{V}$ transport is illustrated in Figure S4, where V flux (kilograms per year) and yield (kilograms per square kilometer per year) are compared to those of unaffected regional watersheds in British Columbia and other miningaffected watercourses around the world. The level of transport of $\mathrm{V}$ in the stream is elevated compared to those of nearby regional streams, even when the flux data are weighted by watershed area. In addition, under high-flow conditions, the $\mathrm{V}$ yield (measured at HC-9 in 2016) was comparable to (lowflow) yield values recorded in Torna Creek, Hungary, following the 2010 Ajka bauxite residue tailings spill. ${ }^{71}$ The $\mathrm{V}$ transport data reported here show a departure from background concentrations and fluxes larger than the departure of those reported for $\mathrm{Cu}$ at Mount Polley. ${ }^{37}$ Particulate transport of $\mathrm{V}$ appeared to be more dominant under high flow than low flow, suggesting physical mobilization of residual tailings could be an important transport mechanism for $\mathrm{V}$ during spring freshets and summer rainfall-runoff events. However, the bulk of the tailings remaining after our sampling in 2015 and 2016 was removed from the Hazeltine Creek watershed and returned to the tailings storage facility (L. Anglin, personal communication, 2018), suggesting that the effects of such physical mobilization could be minimal in the future.

The weathering of mine tailings derived from dam failures such as Mount Polley can play a major role in $\mathrm{V}$ cycling in surficial environments. We have presented evidence that deposition of V-bearing tailings can lead to enhanced pore and inflow water $\mathrm{V}$ concentrations, especially when deposited or stored in environments where dissolution of primary (e.g., $\mathrm{V}$-bearing magnetite and titanite) and secondary (V-bearing $\mathrm{Fe}$ and $\mathrm{Al}$ oxyhydroxides or clay) minerals also leads to greater $\mathrm{V}$ mobilization. However, these enhanced V concentrations can be naturally attenuated, and their potential ecotoxicity reduced, by formation of secondary colloidal $\mathrm{Fe}$ oxyhydroxides that reduce aqueous $\mathrm{V}$ to near background levels.

\section{ASSOCIATED CONTENT}

\section{S Supporting Information}

The Supporting Information is available free of charge on the ACS Publications website at DOI: 10.1021/acs.est.8b06391.

Detailed water sampling and XANES methods and mineral results, pore water geochemical data, PHREEQC modeling results and plots, automated mineralogy data, and plot of $\mathrm{V}$ flux and yield (PDF) 


\section{AUTHOR INFORMATION}

\section{Corresponding Author}

*E-mail: k.hudson-edwards@exeter.ac.uk. Telephone: +44-(0) 1326-259-489.

\section{ORCID}

Karen A. Hudson-Edwards: 0000-0003-3965-2658

Patrick Byrne: 0000-0002-2699-052X

Ian T. Burke: 0000-0002-0484-568X

Notes

The authors declare no competing financial interest.

\section{ACKNOWLEDGMENTS}

The authors thank Lyn Anglin, Colleen Hughes, Art Frye, and Shauna Litke of Mount Polley Mining Corp. for providing site information and data and for field support and access. The authors extend our special thanks to Lyn Anglin for reviewing an early version of the manuscript. The authors also acknowledge Phil Riby, Andy Beard, Agatha Dobosz, and Patrizia Onnis for technical support. The authors thank Diamond Light Source for access to beamline I18 (Proposal SP15046) and Konstantin Ignatyev (Station Scientist, Diamond Light Source Ltd.) for support that contributed to the results presented here. The authors are also grateful to the three anonymous reviewers and Associate Editor Daniel Giammar whose comments significantly improved the manuscript. This research was funded by the UK Natural Environment Research Council (Grant NE/M017486/1). The data used to prepare this paper are available in the manuscript and SI, and from NERC's Environmental Information Data Centre.

\section{REFERENCES}

(1) Kabata-Pendias, A. Trace Elements in Soils and Plants, 4th ed.; CRC Press: Boca Raton, FL, 2011.

(2) Imtiaz, M.; Rizwan, M. S.; Xiong, S.; Li, H.; Ashraf, M.; Shahzad, S. M.; Shahzad, M.; Rizwan, M.; Tu, S. Vanadium, recent advancements and research prospects: a review. Environ. Int. 2015, $80,79-88$.

(3) Goldwaser, I.; Gefel, D.; Gershonov, E.; Fridkin, M.; Shechter, Y. Insulin-like effects of vanadium: basic and clinical implications. $J$. Inorg. Biochem. 2000, 80, 21-25.

(4) McCrindle, C. M. E.; Mokantla, E.; Duncan, N. Peracute vanadium toxicity in cattlegrazing near a vanadium mine. J. Environ. Monit. 2001, 3, 580-582.

(5) Yang, J.; Teng, Y.; Wu, J.; Chen, H.; Wang, G.; Song, L.; Yue, W.; Zuo, R.; Zhai, Y. Current status and associated human health risk of vanadium in soil in China. Chemosphere 2017, 171, 635-643.

(6) Evangelou, A. M. Vanadium in cancer treatment. Crit. Rev. Oncol. 2002, 42, 249-265.

(7) Leonard, A.; Gerber, G. Mutagenicity, carcinogenicity, and teratogenicity of vanadium. Adv. Environ. Sci. Technol. 1998, 31, 143149.

(8) Naeem, A.; Westerhoff, P.; Mustafa, S. Vanadium removal by metal (hydr)oxide adsorbents. Water Res. 2007, 41 (7), 1596-1602.

(9) Huang, J. - H.; Huang, F.; Evans, L.; Glasauer, S. Vanadium: Global (bio)geochemistry. Chem. Geol. 2015, 417, 68-89.

(10) $\mathrm{Hu}, \mathrm{X}$.; Yue, Y.; Peng, X. Release kinetics of vanadium from vanadium titano-magnetite: The effects of $\mathrm{pH}$, dissolved oxygen, temperature and foreign ions. J. Environ. Sci. 2018, 64, 298-305.

(11) Environment and Climate Change Canada. Canadian Environmental Protection Act, 1999. Federal Environmental Quality Guidelines. Vanadium, 2016. http://www.ec.gc.ca/ese-ees/default. asp?lang=En\&n=48D3A655-1 (accessed January 11, 2019).

(12) Schiffer, S.; Liber, K. Estimation of vanadium water quality benchmarks for the protection of aquatic life with relevance to the
Athabasca Oil Sands region using species sensitivity distributions. Environ. Toxicol. Chem. 2017, 36, 3034-3044.

(13) Agency for Toxic Substances and Disease Registry (ATSDR). Toxicological profile for vanadium. 2012. Public Health Service, U.S. Department of Health and Human Services. https://www.atsdr.cdc. gov/toxprofiles/tp58.pdf (accessed July 2, 2018).

(14) Jensen-Fontaine, M.; Norwood, W. P.; Brown, M.; Dixon, D. G.; Le, X. C. Uptake and speciation of vanadium in the benthic invertebrate Hyalella Azteca. Environ. Sci. Technol. 2014, 48, 731-738.

(15) Mišík, M.; Burke, I. T.; Reismüller, M.; Pichler, C.; Rainer, B.; Mišíková, K.; Mayes, W. M.; Knasmueller, S. Red mud a byproduct of aluminum production contains soluble vanadium that causes genotoxic and cytotoxic effects in higher plants. Sci. Total Environ. 2014, 493, 883-890.

(16) Nriagu, J.; Pirrone, N. Emission of vanadium into the atmosphere. In Vanadium in the Environment, Part I: Chemistry and Biochemistry; Nriagu, J., Ed.; Wiley: New York, 1988; pp 25-36.

(17) Shotyk, W.; Belland, R.; Duke, J.; Kempter, H.; Krachler, M.; Noernberg, T.; Pelletier, R.; Vile, M. A.; Wieder, K.; Zaccone, C.; Zhang, S. Sphagnum mosses from 21 ombrotrophic bogs in the Athabasca bituminous sands region show no significant atmospheric contamination of "heavy metals". Environ. Sci. Technol. 2014, 48, 12603-12611.

(18) Yang, J.; Tang, Y.; Yang, K.; Rouff, A. A.; Elzinga, E. J.; Huang, J. H. Leaching characteristics of vanadium in mine tailings and soils near a vanadium titanomagnetite mining site. J. Hazard. Mater. 2014, 264, 498-504.

(19) Cao, X.; Diao, M.; Zhang, B.; Liu, H.; Wang, S.; Yang, M. Spatial distribution of vanadium and microbial community responses in surface soil of Panzhihua mining and smelting area, China. Chemosphere 2017, 183, 9-17.

(20) Watt, J. A. J.; Burke, I. T.; Edwards, R. A.; Malcolm, H. M.; Mayes, W. M.; Olszewska, J. P.; Pan, G.; Graham, M. C.; Heal, K. V.; Rose, N. L.; Turner, S. D.; Spears, B. M. Vanadium: A re-emerging environmental hazard. Environ. Sci. Technol. 2018, 52, 11973-11974.

(21) Burke, I. T.; Peacock, C. L.; Lockwood, D. I.; Stewart, R. J. G.; Mortimer, M. B.; Ward, P.; Renforth, K.; Gruiz, W. M.; Mayes, W. M. Behavior of aluminum, arsenic, and vanadium during the neutralization of red mud leachate by $\mathrm{HCl}$, gypsum, or seawater. Environ. Sci. Technol. 2013, 47, 6527-6535.

(22) Kossoff, D.; Dubbin, W. E.; Alfredsson, M.; Edwards, S. J.; Macklin, M. G.; Hudson-Edwards, K. A. Mine tailings dams: Characteristics, failure, environmental impacts, and remediation. Appl. Geochem. 2014, 51, 229-245.

(23) WISE World Information Service on Energy Uranium Project. Chronology of Major Tailings Dam Failures. 2018. http://www.wiseuranium.org/mdaf.html (accessed July 3, 2018).

(24) Petticrew, E. L.; Albers, S. J.; Baldwin, S. A.; Carmack, E. C.; Dery, S. J.; Gantner, N.; Graves, K. E.; Laval, B.; Morrison, J.; Owens, P. N.; Selbie, D. T.; Vagle, S. The impact of a catastrophic mine tailings impoundment spill into one of North America's largest fjord lakes: Quesnel Lake, British Columbia, Canada. Geophys. Res. Lett. 2015, 42, 3347-3355.

(25) Nikl, L.; Wernick, B.; Van Geest, J.; Hughes, C.; McMahen, K.; Anglin, L. Mount Polley Mine embankment breach: Overview of aquatic impacts and rehabilitation. Proceedings Tailings and Mine Waste, 2016; October 2-5, 2016, Keystone, CO; pp 845-856.

(26) SNC-Lavalin Inc. Mount Polley Mining Corporation post-event environmental impact assessment report. Appendix A: Hydrotechnical and geomorphological assessment. Technical Report 621717; 2015.

(27) Independent Expert Engineering Investigation and Review Panel. Report on Mount Polley Tailings Storage Facility Breach. 2015

(28) MPMC. Mount Polley Mining Corporation post-event environmental impact assessment report: Key findings report. 2015. https://www.imperialmetals.com/assets/docs/mt-polley/2015-06-18MPMC-KFR.pdf.

(29) Golder Associates Ltd. Mount Polley Mining Corporation postevent environmental impact assessment report. Appendix F: Mount Polley Tailings Dam Failure - Surface Water Quality Impact 
Assessment. Technical Report 1411734-036-R-Rev0-10000; 2015; pp $1653-1984$.

(30) Hudson-Edwards, K. A.; Macklin, M. G.; Jamieson, H. E.; Brewer, P. A.; Coulthard, T. J.; Howard, A. J.; Turner, J. N. The impact of tailings dam spills and clean-up on sediment and water quality in river systems: The Ríos Agrio-Guadiamar, Aznalcóllar, Spain. Appl. Geochem. 2003, 18, 221-239.

(31) Bird, G.; Brewer, P. A.; Macklin, M. G.; Balteanu, D.; Serban, M.; Driga, B.; Zaharia, S. River system recovery following the NovatRosu tailings dam failure, Maramures County, Romania. Appl. Geochem. 2008, 23, 3498-3518.

(32) Golder Associates Inc. Mount Polley rehabilitation and remediation strategy: Detailed site investigation Mount Polley tailings dam failure Mount Polley, BC. Technical Report 1411734-114-RRev0-11000; 2016.

(33) Golder Associates Ltd. Mount Polley Mining Corporation postevent environmental impact assessment report. Appendix I: Mount Polley Tailings Dam Failure - Post-event Water Quality August 2014 through April 2015. 2015.

(34) Minnow Environmental Inc. Mount Polley Mining Corporation Post-even Environmental Impact Assessment Report. Appendix E: Mount Polley mine tailings dam failure: Sediment quality impact characterization. 2015.

(35) Mount Polley Mine Tailings Dam Failure: Update on Geochemical Characterization of Spilled Tailings. SRK Consulting (Canada) Inc.: Vancouver, BC, 2015.

(36) SRK Consulting (Canada) Inc. Mount Polley Mining Corporation post-event environmental impact assessment report. Appendix C: Mount Polley Tailings Dam Failure - Geochemical characterisation of spilled tailings. Technical Report 1CI008.003; 2015.

(37) Byrne, P.; Hudson-Edwards, K. A.; Bird, G.; Macklin, M. G.; Brewer, P. A.; Williams, R. D.; Jamieson, H. E. Water quality impacts and river system recovery following the 2014 Mount Polley mine tailings dam spill, British Columbia, Canada. Appl. Geochem. 2018, 91, 64-74.

(38) McMillan, W. J. Porphyry deposits of the Canadian cordillera. Geoscience Canada 1996, 23, 125-134.

(39) Minnow Environmental Inc. Mount Polley Mine Aquatic Environmental Characterization - 2007. 2009.

(40) Ball, J. W.; Nordstrom, D. K. User's manual for WATEQ4F, with revised thermodynamic database and test cases for calculating speciation of major, trace, and redox elements in natural waters. U.S. Geological Survey Open-File Report; 1991; 91-183, p 189.

(41) Parkhurst, D. L.; Appelo, C. A. J. Description of input and examples for PHREEQC version 3: A computer program for speciation, batch-reaction, one-dimensional transport, and inverse geochemical calculations. U.S. Geological Survey Techniques and Methods; Book 6, Chapter A43, pp 497; 2013.

(42) Ravel, B.; Newville, M. ATHENA, ARTEMIS, HEPHAESTUS: data analysis for X-ray absorption spectroscopy using IFEFFIT. $J$. Synchrotron Radiat. 2005, 12, 537-541.

(43) Chaurand, P.; Rose, J.; Briois, V.; Salome, M.; Proux, O.; Nassif, V.; Olivi, L.; Susini, J.; Hazemann, J. - L.; Bottero, J. - Y. New methodological approach for the vanadium K-edge X-ray absorption near-edge structure interpretation: Application to the speciation of vanadium in oxide phases from steel slag. J. Phys. Chem. B 2007, 111, 5101-5110.

(44) Burke, I. T.; Mayes, W. M.; Peacock, C. L.; Brown, A. P.; Jarvis, A. P.; Gruiz, K. Speciation of arsenic, chromium, and vanadium in red mud samples from the Ajka spill site, Hungary. Environ. Sci. Technol. 2012, 46, 3085-3092.

(45) Shiller, A. M.; Boyle, E. A. Dissolved vanadium in rivers and estuaries. Earth Planet. Sci. Lett. 1987, 86, 214-224.

(46) Wright, M. T.; Stollenwerk, K. G.; Belitz, K. Assessing the solubility controls on vanadium in groundwater, northeastern San Joaquin Valley, CA. Appl. Geochem. 2014, 48, 41-52.
(47) Wehrli, B.; Stumm, W. Vanadyl in natural waters: Adsorption and hydrolysis promote oxygenation. Geochim. Cosmochim. Acta 1989, 53, 69-77.

(48) Lu, X. Q.; Johnson, W. D.; Hook, J. Reaction of vanadate with aquatic humic substances: an ESR and V-51 NMR study. Environ. Sci. Technol. 1998, 32, 2257-22263.

(49) Levshina, S. An assessment of metal-humus complexes in river waters of the Upper Amur basin, Russia. Environ. Monit. Assess. 2018, 190, 18.

(50) Wong, H. K. T.; Gauthier, A.; Nriagu, J. O. Dispersion and toxicity of metals from abandoned gold mine tailings at Goldenville, Nova Scotia, Canada. Sci. Total Environ. 1999, 228, 35-47.

(51) Gleisner, M.; Herbert, R. B. Sulfide mineral oxidation in freshly processed tailings: batch experiments. J. Geochem. Explor. 2002, 76, $139-153$.

(52) Kennedy, C. B.; Day, S. J.; Anglin, C. D. Geochemistry of tailings from the Mount Polley Mine, British Columbia. Proceedings Tailings and Mine Waste, 2016; October 2-5, 2016, Keystone, CO; pp 857-868.

(53) Celis, A. Titanite as an indicator mineral for alkalic porphyry $\mathrm{Cu}$ $\mathrm{Au}$ deposits in south-central British Columbia; DOI: 10.14288/ $1.0166663,2015$.

(54) Peacock, C. L.; Sherman, D. M. Vanadium(V) adsorpton onto goethite $(\alpha-\mathrm{FeOOH})$ at $\mathrm{pH} 1.5$ to 12 : a surface complexation model based on ab initio molecular geometries and EXAFS spectroscopy. Geochim. Cosmochim. Acta 2004, 68, 1723-1733.

(55) Chaurand, P.; Rose, J.; Briois, V.; Salome, M.; Proux, O.; Nassif, V.; Olivi, L.; Susini, J.; Hazemann, J.-L.; Bottero, J.-Y. New methodological approach for the vanadium K-edge X-ray absorption near-edge structure interpretation: Application to the speciation of vanadium in oxide phases from steel slag. J. Phys. Chem. B 2007, 111, $5101-5110$.

(56) Hobson, A. J.; Stewart, D. I.; Bray, A. W.; Mortimer, R. J. G.; Mayes, W. M.; Riley, A. L.; Rogerson, M.; Burke, I. T. Behaviour and fate of vanadium during the aerobic neutralisation of hyperalkaline slag leachate. Sci. Total Environ. 2018, 643, 1191-1199.

(57) Toplis, M. J.; Corgne, A. An experimental study of element partitioning between magnetite, clinopyroxene and iron-bearing silicate liquids with particular emphasis on vanadium. Contrib. Mineral. Petrol. 2002, 144, 22-37.

(58) Balan, E.; de Villiers, J. P. R.; Eeckhout, S. G.; Glatzel, P.; Toplis, M. J.; Fritsch, E.; Allard, T.; Galoisy, L.; Calas, G. The oxidation state of vanadium in titanomagnetite from layered basic intrusions. Am. Mineral. 2006, 91, 953-956.

(59) Canil, D.; Grondahl, C.; Lacourse, T.; Pisiak, L. K. Trace elements in magnetite from porphyry $\mathrm{Cu}-\mathrm{Mo}$-Au deposits in British Columbia, Canada. Ore Geol. Rev. 2016, 72, 1116-1128.

(60) Pan, Y.; Fleet, M. E. Vanadium-rich minerals of the pumpellyite group from the Hemlo gold deposit, Ontario. Can. Mineral. 1992, 30, $153-162$.

(61) Shannon, R. D. Revised effective ionic radii and systematic studies of interatomic distances in halides and chalcogenides. Acta Crystallogr., Sect. A: Cryst. Phys., Diffr., Theor. Gen. Crystallogr. 1976, A32, 751-767.

(62) Wehrli, B.; Stumm, W. Vanadyl in natural waters - Adsorption and hydrolysis promote oxygenation. Geochim. Cosmochim. Acta 1989, 53, 69-7.

(63) Schwertmann, U.; Pfab, G. Structural vanadium in synthetic goethite. Geochim. Cosmochim. Acta 1994, 58, 4349-4352.

(64) Larsson, M. A.; Persson, I.; Sjöstedt, C.; Gustafsson, J. P. Vanadate complexation to ferrihydrite: X-ray absorption spectroscopy and CD-MUSIC modelling. Environ. Chem. 2017, 14, 141-150.

(65) Kaur, N.; Singh, B.; Kennedy, B. J.; Gräfe, M. The preparation and characterization of vanadium-substituted goethite: The importance of temperature. Geochim. Cosmochim. Acta 2009, 73, 582-593.

(66) Surridge, B. W. J.; Heathwaite, A. L.; Baird, A. J. The release of phosphorus to porewater and surface water from river riparian sediments. J. Environ. Qual. 2007, 36, 1534-1544. 
(67) Tilley, D. B.; Eggleton, R. A. Titanite low-temperature alteration and Ti mobility. Clays Clay Miner. 2005, 53, 100-107.

(68) Dzombak, D. A.; Morel, F. M. M. Surface Complexation Modelling: Hydrous Ferric Oxide; Wiley-Interscience: New York, 1990.

(69) Wällstedt, T.; Björkvald, L.; Gustafsson, J. P. Increasing concentrations of arsenic and vanadium in (southern) Swedish streams. Appl. Geochem. 2010, 25, 1162-1175.

(70) Dahlqvist, R.; Andersson, K.; Ingri, J.; Larsson, T.; Stolpe, B.; Turner, D. Temporal variations of colloidal carrier phases and associated trace elements in a boreal river. Geochim. Cosmochim. Acta 2007, 71, 5339-5354.

(71) Mayes, W. M.; Jarvis, A. P.; Burke, I. T.; Walton, M.; Feigl, V.; Klebercz, O.; Gruiz, K. Dispersal and attenuation of trace contaminants downstream of the Ajka bauxite residue (red mud) depository failure, Hungary. Environ. Sci. Technol. 2011, 45, 51475155.

(72) Hobson, A. J.; Stewart, D. I.; Bray, A. W.; Mortimer, R. J. G.; Mayes, W. M.; Rogerson, M.; Burke, I. T. Mechanism of vanadium leaching during surface weathering of basic oxygen furnace steel slag blocks: A microfocus X-ray absorption spectroscopy and electron microscopy study. Environ. Sci. Technol. 2017, 51, 7823-7830.

(73) Bronkema, J. L.; Bell, A. T. Mechanistic studies of methanol oxidation to formaldehyde on isolated vanadate sites supported on MCM-48. J. Phys. Chem. C 2007, 111, 420-430.

(74) Wong, J.; Lytle, F. W.; Messmer, R. P.; Maylotte, D. H. K-edge absorption-spectra of selected vanadium compounds. Phys. Rev. B:

Condens. Matter Mater. Phys. 1984, 30, 5596-5610. 